\title{
СТОМАТОЛОГІЯ
}

(C) В.С. Мельник, Л.Ф. Горзов, К.В. Зомбор, В.В. Горзов, 2018

УДК 616.314-084-053.2(477.87)

\section{Моніторинг стоматологічного здоров'я дітей та підлітків Закарпатської області}

\author{
В.С. Мельник, Л.Ф. Горзов, К.В. Зомбор, В.В. Горзов \\ volodymyr.melnyk@uzhnu.edu.ua
}

Ужсгородський національний університет, стоматологічний факультет, кафедра дитячої стоматологї, Уэсгород

\section{Реферат}

Вступ. Вивчення епідеміології стоматологічних захворювань серед дитячого населення лежить в основі планування та організації стоматологічної допомоги дітям.

Мета дослідження. Визначити потреби дітей та підлітків Закарпатської області в профілактичній та лікувальній стоматологічній допомозі.

Матеріали та методи. Проведено стоматологічне епідеміологічне обстеження дитячого населення в м. Ужгород, м. Мукачево, Перечинському, Хустському, Берегівському, Тячівському та Рахівському районах. У результаті епідеміологічного дослідження було оглянуто 760 осіб у вікових групах: $6,12,15$ років.

Результати досліджень та їх обговорення. Поширеність карієсу зубів у 6 і 15- річних дітей оцінена як висока, а у 12-річних - як середня. Аналіз показників індивідуального ураження карієсом зубів показав, що кожна дитина у віці 6 років має по $4,42 \pm 0,02$, у віці 12 років- по $2,2 \pm 0,03$, а у віці 15 років- по $3,38 \pm 0,03$ каріозних зуба. Гігієна порожнини рота у дітей всіх вікових груп задовільна. Стан тканин пародонта за індексом КПІ у дітей 12 і 15 років оцінено як ризик виникнення захворювань. Рівень надання стоматологічної допомоги дітям у віці 6 років - незадовільний, у віці 12 років - задовільний, у віці 15 років - добрий.

Висновки. Діти у віці 6 і 15 років, котрі проживають в районах Закарпатської області, мають високу, а у віці 12 років середню поширеність карієсу зубів. Інтенсивність карієсу зубів оцінена як середня. Гігієна ротової порожнини у дітей всіх вікових груп задовільна. Завдання медичних працівників, крім надання лікувальної допомоги, повинно полягати у регулярному санітарно-гігієнічному вихованні населення, і перш за все дітей, 3 метою вироблення у них стійких навичок по догляду за ротовою порожниною.

Ключові слова: епідеміологія, поширеність, інтенсивність, карієс зубів, хвороби тканин пародонта

Monitoring of stomatological health of children and adults of transcarpathian region

V.S. Melnyk, L.F. Horzov, K.V. Zombor, V.V. Horzov

Uzhhorod National University, Faculty of Dentistry, Department of Pediatric Dentistry, Uzhhorod

\section{Abstract}

Introduction. The study of the epidemiology of stomatological diseases among the children is at the heart of the planning and organization of dental care for children.

The aim of the study. Identify the needs of children and adolescents in the Transcarpathian region in preventive and therapeutic dental care. Materials and methods. A dental epidemiological survey of the children's population was carried out in Uzhhorod, Mukachevo, Perechyn, Khust, Berehove, Tyachiv and Rakhiv districts. As a result of the epidemiological study 760 people in the age groups: $6,12,15$ years were examined. The research is devoted to the study of the needs of children and adolescents in Transcarpathia in the provision of dental care. As a result of the epidemiological study 760 people in the age groups: $6,12,15$ years were examined.

Results of the research and their discussion. The prevalence of dental caries in children aged 6 and 15 years is estimated to be high, and at 12 years of age it is an average. Analysis of the indicators of individual lesion of tooth decay showed that every child at the age of 6 years has a $4.42 \pm 0.02$, at the age of 12 years- by $2.2 \pm 0.03$, and at the age of 15 years- by $3.38 \pm 0.03$ carious teeth. Hygiene of the oral cavity in children of all age groups is satisfactory. The state of periodontal tissues according to the KPI index in children 12 and 15 years is assessed as a risk of disease. The level of dental care for children aged 6 years- unsatisfactory, at the age of 12 years- satisfactory, at the age of 15 years-is good.

Conclusions. Children aged 6 and 15 living in areas of Transcarpathia have high, and at the age of 12 years the average prevalence of caries. Intensity of caries is estimated as average. Hygiene of oral cavity in children of all age groups is satisfactory. The task of health workers, in addition to medical help should be regular sanitary-hygienic education of the population, and especially children, to develop their skills in sustainable oral care.

Key words: epidemiology, prevalence, intensity, dental caries, periodontal tissue diseases

Вступ. Вивчення епідеміології стоматологічних захворювань серед дитячого населення лежить в основі планування та організації стоматологічної допомоги дітям, виявлення потреби в профілактиці 
та лікуванні, а також дозволяє оцінити якісний рівень лікувальних і профілактичних заходів, порівняти стан захворюваності в різних регіонах [1].

Опубліковані в літературі результати епідеміологічних досліджень, проведених в Одесі, Києві, Полтаві, Львові, стимулювали дослідників проводити подібні спостереження в своєму регіоні 3 урахуванням потреби практичної охорони здоров'я і наукової доцільності $[2,3,4]$.

Дані про поширеність та інтенсивність карієсу зубів серед дитячого населення Закарпатської області повідомляються в низціробіт $[5,6]$. У більшості цих публікацій відзначений стабільно високий рівень поширеності та інтенсивності карієсу зубів у дітей. У даний час в період пошуку моделі найбільшої ефективності стоматологічної служби назріла необхідність в повноцінній інформації про рівень захворюваності зубів, тканин пародонту, стану гігієни ротової порожнини та потреби в наданні стоматологічної допомоги дітям та підліткам Закарпатської області [7].

Мета дослідження. Визначити потреби дітей та підлітків Закарпатської області в профілактичній та лікувальній стоматологічній допомозі.

Матеріали та методи. Для досягнення поставленої мети в січні 2018 року проведено стоматологічне епідеміологічне обстеження дитячого населення в м. Ужгород, м. Мукачево, Перечинському, Хустському, Берегівському, Тячівському та Рахівському районах. Стоматологічне обстеження дитячого населення проводили співробітники кафедри дитячої стоматології стоматологічного факультету УжНУ разом зі студентами 5 курсу під час проходження ними виробничої практики 3 дитячої стоматології. Лікарі та студенти 5 курсу стоматологічного факультету УжНУ, які брали участь у стоматологічному огляді дітей, попередньо пройшли дводенний курс навчання (калібровки) для забезпечення стандартного підходу в діагностиці патологічних станів зубів і тканин пародонта.
Об'єктами обстеження були діти, які відвідують та навчаються у дошкільних та загальноосвітніх навчальних закладах міст Ужгород, Мукачево та 5 районів області.

Стоматологічне епідеміологічне обстеження проводилося відповідно до рекомендацій ВОО3 у вікових групах: 6,12 і 15 років. У кожній віковій групі обстежено по 30 хлопчиків і 30 дівчаток 3 числа практично здорових дітей, котрі постійно проживають у даній місцевості. Огляд ротової порожнини проводився в умовах стоматологічного кабінету за допомогою набору стоматологічного інструментарію (стоматологічне дзеркало, зонд). Дані клінічних спостережень фіксували в картах обстеження стану ротової порожнини у дітей, запропонованих ДУ «Інститутом стоматології АМН України м. Одеса».

Епідеміологічне обстеження дітей проведено в 7 установах освіти, що забезпечують отримання дошкільної освіти та в 14 навчальних закладах загальної середньої освіти. Всього було оглянуто 760 осіб трьох вікових груп 3 гендерним розподілом за статтю.

У ході епідеміологічного стоматологічного обстеження вивчена поширеність та інтенсивність карієсу зубів за індексами кп, КПВ + кп, КПВ, стан тканин пародонта за індексом КПІ, стан гігієни ротової порожнини за індексом Green-Vermillion (OHI-S) та Silness-Loe у дітей різних вікових груп $(6,12,15$ років), визначений рівень надання стоматологічної допомоги дитячому населенню $[8,9,10]$.

Результати дослідження та їх обговорення. В результаті обстеження встановлено, що в цілому по Закарпатській області 86,02 $\pm 0,68 \%$ дітей у віці 6 років, 79,42 $\pm 0,78 \%$ у віці 12 років і $91,63 \pm 0,67 \%$ у віці 15 років мають зуби, уражені карієсом (табл. 1). Поширеність карієсу зубів у 6 i 15-річних дітей оцінена як висока, а у 12річних - як середня.

Таблиця 1

Стоматологічний статус дитячого населення, котре проживає на Закарпатті $(\mathrm{M} \pm \mathrm{m})$

\begin{tabular}{|l|c|c|c|}
\hline \multicolumn{1}{|c|}{ Вік (років) } & 6 & 12 & 15 \\
\hline Поширеність карієсу (\%) & $86,02 \pm 0,68$ & $79,42 \pm 0,78$ & $91,63 \pm 0,67$ \\
\hline Інтенсивність карієсу (кпв) & $4,35 \pm 0,01$ & $0,06 \pm 0,002$ & 0 \\
\hline Інтенсивність карієсу (КПВ) & $0,07 \pm 0,002$ & $2,14 \pm 0,003$ & $3,38 \pm 0,04$ \\
\hline Інтенсивність карієсу (КПВ + кп) & $4,42 \pm 0,02$ & $2,2 \pm 0,03$ & $3,38 \pm 0,03$ \\
\hline Стан гігієни порожнини рота (ОНІ-S) & $1,00 \pm 0,02$ & $1,05 \pm 0,02$ & $0,96 \pm 0,02$ \\
\hline Стан тканин пародонту (КПІ) & & $0,89 \pm 0,01$ & $0,85 \pm 0,01$ \\
\hline Рівень надання стоматологічної допомоги (\%) & $43,54 \pm 0,84$ & $73,2 \pm 0,75$ & $75,46 \pm 0,72$ \\
\hline
\end{tabular}

Аналіз показників індивідуального ураження карієсом зубів показав, що кожна дитина у віці 6 років має по $4,42 \pm 0,02$, у віці 12 роківпо 2,2 $\pm 0,03$, а у віці 15 років - по $3,38 \pm 0,03$ каріозних зуба. Причому у 6-річних дітей зареєс-

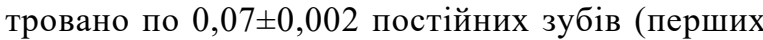

постійних великих кутніх зубів), уражених карієсом. Інтенсивність карієсу зубів за індексом КПВ+кп у дітей усіх вікових груп оцінена як середня.

Вивчення показників гігієнічного стану ротової порожнини у дітей обстежених вікових груп 
показало наявність м'яких і твердих зубних відкладень на зубах, що свідчить про недостатнє їх очищення. Середнє значення гігієнічного індекcy PLI у 6-річних дітей склало $1,00 \pm 0,02$, а гігієнічного індексу OHI-S у 12- і 15-річних школя-

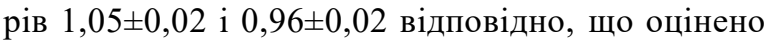
як задовільна гігієна ротової порожнини.

Стан тканин пародонта вивчали за допомогою комплексного періодонтального індексу (КПІ). Встановлено, що у дітей у віці 12 і 15 років цей показник склав $0,89 \pm 0,01$ і 0,85 $\pm 0,01$ відповідно, що свідчить про наявність ризику виникнення захворювання.
Аналізуючи рівень надання стоматологічної допомоги дитячому населенню в обстежених вікових групах, виявлено, що 43,54 $\pm 0,84 \%$ дітей у віці 6 років надана стоматологічна допомога в необхідному обсязі, і цей показник оцінений як недостатній. У віці 12 років 73,2 $\pm 0,75 \%$ дитячого населення отримало необхідну кваліфіковану стоматологічну допомогу, i показник оцінений як задовільний. Рівень стоматологічної допомоги дитячому населенню у віці 15 років склав $75,46 \pm 0,72 \%$ і оцінений як хороший.

У таблиці 2 представлені дані стоматологічного статусу дітей, котрі проживають у Закарпатській області.

Таблиця 2

Стоматологічний статус дитячого населення, яке проживає у Закарпатській області (M \pm m)

\begin{tabular}{|c|c|c|c|c|c|c|c|}
\hline Район & 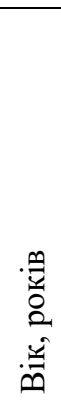 & 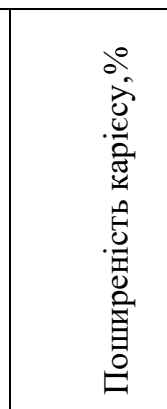 & 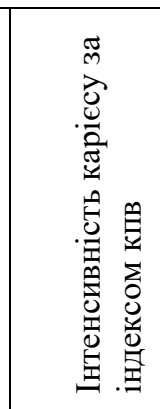 & 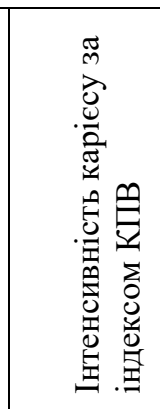 & 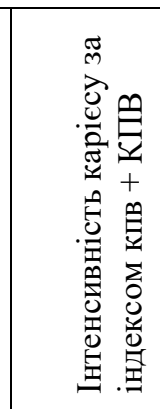 & 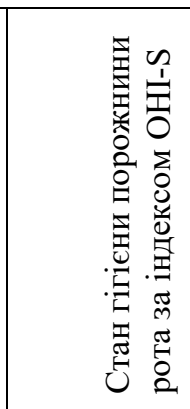 & 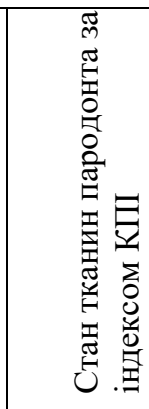 \\
\hline \multirow{3}{*}{ м.Ужгород } & 6 & $72,6 \pm 3,32$ & $3,98 \pm 0,12$ & $0,04 \pm 0,01$ & $4,02 \pm 0,21$ & $1,23 \pm 0,03$ & - \\
\hline & 12 & $72,1 \pm 3,34$ & $0,26 \pm 0,01$ & $2,24 \pm 0,21$ & $2,5 \pm 0,08$ & $1,34 \pm 0,04$ & $1,01 \pm 0,18$ \\
\hline & 15 & $83,2 \pm 2,78$ & 0 & $4,0 \pm 0,15$ & $4,0 \pm 0,31$ & $1,05 \pm 0,02$ & $0,88 \pm 0,09$ \\
\hline \multirow{3}{*}{ м.Мукачево } & 6 & $69,7 \pm 3,42$ & $2,65 \pm 0,03$ & 0 & $2,65 \pm 0,21$ & $0,81 \pm 0,02$ & - \\
\hline & 12 & $61,2 \pm 3,63$ & 0 & $1,5 \pm 0,09$ & $1,5 \pm 0,15$ & $0,57 \pm 0,04$ & $0,57 \pm 0,05$ \\
\hline & 15 & $69,7 \pm 3,42$ & 0 & $2,35 \pm 0,12$ & $2,35 \pm 0,25$ & $0,47 \pm 0,03$ & $0,47 \pm 0,04$ \\
\hline \multirow{3}{*}{ Перечинський } & 6 & $80,8 \pm 2,93$ & $3,9 \pm 0,05$ & $0,11 \pm 0,06$ & $4,01 \pm 0,34$ & $1,23 \pm 0,08$ & - \\
\hline & 12 & $72,7 \pm 3,32$ & $0,19 \pm 0,01$ & $2,48 \pm 0,08$ & $2,67 \pm 0,28$ & $1,31 \pm 0,09$ & $1,00 \pm 0,89$ \\
\hline & 15 & $89,4 \pm 2,29$ & 0 & $4,06 \pm 0,22$ & $4,06 \pm 0,38$ & $1,31 \pm 0,09$ & $1,07 \pm 0,88$ \\
\hline \multirow{3}{*}{ Хустський } & 6 & $79,4 \pm 3,01$ & $4,12 \pm 0,12$ & 0 & $4,12 \pm 0,24$ & $0,91 \pm 0,07$ & - \\
\hline & 12 & $67,1 \pm 3,5$ & 0 & $2,01 \pm 0,05$ & $2,01 \pm 0,15$ & $0,78 \pm 0,06$ & $0,86 \pm 0,09$ \\
\hline & 15 & $81,4 \pm 2,9$ & 0 & $3,3 \pm 0,15$ & $3,3 \pm 0,19$ & $0,79 \pm 0,06$ & $0,88 \pm 0,09$ \\
\hline \multirow{3}{*}{ Берегівський } & 6 & $86,7 \pm 1,46$ & $6,13 \pm 0,23$ & $0,14 \pm 0,01$ & $6,27 \pm 0,42$ & $1,03 \pm 0,09$ & - \\
\hline & 12 & $68,8 \pm 1,40$ & 0 & $2,06 \pm 0,19$ & $2,06 \pm 0,21$ & $0,88 \pm 0,06$ & $0,89 \pm 0,09$ \\
\hline & 15 & $79,3 \pm 1,21$ & 0 & $2,95 \pm 0,24$ & $2,95 \pm 0,22$ & $0,97 \pm 0,08$ & $0,96 \pm 0,11$ \\
\hline \multirow{3}{*}{ Тячівський } & 6 & $84,8 \pm 1,45$ & $4,89 \pm 0,18$ & $0,18 \pm 0,04$ & $5,07 \pm 0,31$ & $0,97 \pm 0,08$ & - \\
\hline & 12 & $74,0 \pm 1,33$ & 0 & $2,58 \pm 0,14$ & $2,58 \pm 0,21$ & $1,27 \pm 0,11$ & $0,9 \pm 0,011$ \\
\hline & 15 & $82,4 \pm 1,15$ & 0 & $3,62 \pm 0,16$ & $3,62 \pm 0,26$ & $1,07 \pm 0,10$ & $0,82 \pm 0,08$ \\
\hline \multirow{3}{*}{ Рахівський } & 6 & $86,0 \pm 1,49$ & $4,8 \pm 0,16$ & $0,04 \pm 0,01$ & $4.84 \pm 0,32$ & $0,83 \pm 0,09$ & - \\
\hline & 12 & $70,0 \pm 1,39$ & 0 & $2,1 \pm 0,18$ & $2,13 \pm 0,19$ & $1,20 \pm 0,12$ & $1.0 \pm 0,12$ \\
\hline & 15 & $79,0 \pm 1,23$ & 0 & $3,4 \pm 0,21$ & $3,40 \pm 0,26$ & $1,10 \pm 0,11$ & $0.9 \pm 0,14$ \\
\hline
\end{tabular}

Аналіз вивчених показників стоматологічної захворюваності в Закарпатській області показав, що найбільше $(86,7 \pm 1,46 \%)$ число дітей 3 каріозними ураженнями у віці 6 років проживають у Берегівському районі, а найменше $(79,4 \pm 3,01 \%)-$ у Хустському. Серед 12-річних дітей поширеність карієсу зубів найвища $(74,0 \pm 1,33 \%)$ у Тячівському, a найменша $(67,1 \pm 3,5 \%)$ - у Хустському районі. Майже 90\% дітей у віці 15 років, що проживають у
Перечинському районі, мають ураження зубів карієсом. Це найбільший показник в названій віковій групі, а найменший $(69,7 \pm 3,42 \%)$ зареєстрований у 15-річних дітей, котрі проживають в м. Мукачево.

Показник індивідуального ураження зубів карієсом у дітей у віці 6 років коливався від 2,65 $\pm 0,21$ зуба в м. Мукачево до $6,27 \pm 0,42$ зуба на одну дитину в Берегівському районі. Причому у всіх районах області, крім Хустського і м. Мукачева, діти 
вищеназваного віку вже мали постійні зуба, уражені карієсом (від 0,04 $\pm 0,01$ зуба у м. Ужгород та Рахівському районі до $0,18 \pm 0,04$ зубів в Тячівському районі). У 12-річному віці найменше $(1,5 \pm$ $0,15)$ кількість зубів, уражених карієсом, мали діти, які проживають в м. Мукачево, а найбільше $(2,67 \pm 0,28)$ - в Перечинському районі. Серед 15 річних жителів Закарпатської області показник індивідуального ураження зубів карієсом коливався від 2,35 $\pm 0,25$ зуба в м. Мукачево до 4,06 $\pm 0,38$ зуба в Перечинському районі.

Найкращі показники гігієнічного стану ротової порожнини зареєстровані у 6-річних дітей, які проживають у Рахівському районі, і у 12- і 15 річних дітей, котрі проживають у Хустському районі. Дещо гірше доглядають за зубами діти трьох обстежених груп, які проживають у м. Ужгород та Перечинському районі.

Стан тканин пародонта оцінювали за допомогою комплексного періодонтального індексу, який склав у дітей у віці 12 років, які проживають у м. Ужгород (КПI $=1,01 \pm 0,18)$, i 15 років, що проживають в Перечинському районі (КПI $=1,07 \pm 0,88)$, оцінено як легка форма захворювання, а у решти обстежених дітей- як ризик виникнення захворювань тканин пародонта.

Висновки. 1. Діти у віці 6 і 15 років, котрі проживають в районах Закарпатської області, мають високу, а у віці 12 років середню поширеність карієсу зубів.

2. Інтенсивність карієсу зубів за індексом інтенсивності карієсу зубів у дітей 6,12 і 15 років оцінена як середня.

3. Гігієна ротової порожнини у дітей всіх вікових груп задовільна. Стан тканин пародонта за індексом КПІ у дітей 12 і 15 років оцінено як ризик виникнення захворювань.

4. Рівень надання стоматологічної допомоги (РСД) дітям у віці 6 років - незадовільний, у віці 12 років - задовільний, у віці 15 років- хороший.

5. Завдання медичних працівників, крім надання лікувальної допомоги, повинно полягати у регулярному санітарно-гігієнічному вихованні населення, і перш за все дітей, з метою вироблення у них стійких навичок по догляду за ротовою порожниною.

Інформація про конфлікт інтересів. Автори заявляють про відсутність конфлікту інтересів при виконанні наукового дослідження та підготовці даної статті.

Інформація про фінансування. Автори гарантують, що вони не отримували жодних винагород в будь-якій формі, здатних вплинути на результати роботи.

Особистий внесок кожного автора у виконання роботи:

Мельник В.С. - розробка концепції і дизайну дослідження, аналіз отриманих даних, редагування;

Горзов Л.Ф. - збір матеріалу, статистична обробка даних, підготовка тексту;

Зомбор К.В. - збір матеріалу, аналіз отриманих даних;

Горзов В.В. - збір матеріалу, аналіз отриманих даних, підготовка тексту статті.

\section{Список використаної літератури}

1. Kaskova LF, Levchenko NV, Andrianova OIu. Epidemiolohichni doslidzhennia - osnova planuvannia zakhodiv profilaktyky stomatolohichnykh khvorob u ditei. Ukrainskyi stomatolohichnyi almanakh. 2011;2:25 6. [In Ukrainian].

2. Savychuk NO. Stomatolohichne zdorovia ditei, metodolohichni pidkhody ta kryterii otsinky. Sovremennaia stomatolohyia. 2008; 1: 94 - 8. [In Ukrainian].

3. Smoliar NI, Bezvushko EV, Chukhrai NL, Dubetska IS. Stomatolohichna zakhvoriuvanist ditei Lvivshchyny. Lviv: 2009;30. [In Ukrainian].

4. Lazoryshynets VV. Stomatolohichna dopomoha v Ukraini. Kyiv:2010;87. [In Ukrainian].

5. Klitynska OV, Melnyk VS, Stupnytska OM. Analiz stanu tkanyn parodonta u shkoliariv mista Uzhhoroda. Ukrainskyi medychnyi almanakh.2012; 15(3):89-90. [In Ukrainian].

6. Melnyk VS, Horzov LF, Sabov AV. Epidemiolohiia stomatolohichnykh zakhvoriuvan sered dytiachoho naselennia Zakarpattia. Aktualni problemy suchasnoi medytsyny. 2016;16,3(55):20-2. [In Ukrainian].

7. Holubchykov MV, Kaniura OA, Savychuk NO. Osnovni napriamy reformuvannia dytiachoi stomatolohichnoi sluzhby. Kyiv. 2010; 112. [In Ukrainian].

8. World Health Organization. Oral Health Surveys: Basic Methods. 4th. Geneva, Switzerland: World Health Organization; 1997.

9. Savichuk NO. Sovremennyie podhodyi k izucheniyu stomatologicheskogo zdorovya. Dentalnyie tehnolog.i.2010;2: 7-10. [In Russian].

10. Loe H. Oral hygiene in the prevention of caries and periodontal disease. Int. Dent. J. 2000; 50(3): 129-139.

\section{Стаття надійшла до редакції: 13.02.2018 р.}

